\title{
DISTRIBUTION OF FALSE INFORMATION DISCREDITING THE HONOR AND DIGNITY OF THE PERSON OR THE COMPANY UNDER THE U.S. LEGISLATION
}

\author{
Vladimir V. Yastrebov \\ Peoples' Friendship University of Russia, Moscow, Russian Federation
}

Introduction: the article is devoted to the study of the main provisions of the legislative regulation of mechanisms for protecting business reputation in the United States To this end, the author is studying the legal nature of defamation, which is directly related to the business reputation, namely, its protection. Using the methods of scientific knowledge, first of all, the method of systemic and comparative analysis, the author identifies the conditions for the occurrence of liability for the dissemination of defamatory information under US law. Results indicate that English law had a huge impact on the legal regulation of defamation in the United States; despite the existence of legal regulation of the analyzed legal phenomenon in the legislation of each state, the author outlines the general conditions of responsibility for the dissemination of false information; defamation is a civil offense; The basic principle on which the legal regulation of defamation is based is the priority of the right to freedom of speech over the right to protection of honor, dignity and reputation. Conclusions: the author made a conclusion on a sufficiently detailed and balanced legal regulation of defamation in the United States, and on the need for the reception of a number of provisions in Russian legislation, which has quite a few gaps in creating an effective mechanism for protecting business reputation.

Key words: defamation, image, delict, Law on ensuring the protection of constitutional heritage, common law, state law, business reputation, honor, dignity, civil offence, reputation.

Citation. Yastrebov V.V. Distribution of False Information Discrediting the Honor and Dignity of the Person or the Company Under the U.S. Legislation. Legal Concept, 2018, vol. 17, no. 4, pp. 113-116. DOI: https://doi.org/ 10.15688/lc.jvolsu.2018.4.16

\section{РАСПРОСТРАНЕНИЕ ЛОЖНЫХ, НЕВЕРНЫХ СВЕДЕНИЙ, ПОРОЧАЩИХ ЧЕСТЬ И ДОСТОИНСТВО ЛИЦА ИЛИ КОМПАНИИ ПО ЗАКОНОДАТЕЛЬСТВУ США}

\author{
Владимир Валерьевич Ястребов \\ Российский университет дружбы народов, г. Москва, Российская Федерация
}

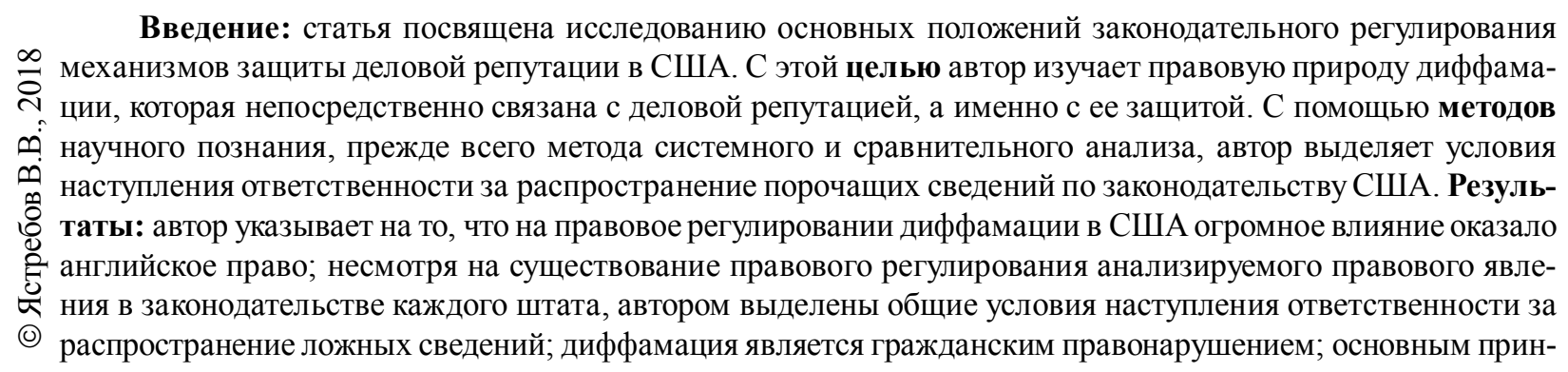


ципом, на котором строится правовое регулирование диффамации, является приоритет права свободы слова перед правом на защиту чести, достоинства и репутации. Выводы: автором сделан вывод о достаточно подробном и сбалансированном правовом регулировании диффамации в США и о необходимости рецепции ряда положений в российское законодательство, которое имеет достаточно много пробелов в создании действенного механизма защиты деловой репутации.

Ключевые слова: диффамация, имидж, деликт, «Закон об обеспечении защиты конституционного наследия», общее право, законодательство штатов, деловая репутация, честь, достоинство, гражданское правонарушение, репутация.

Цитирование. Ястребов В. В. Распространение ложных, неверных сведений, порочащих честь и достоинство лица или компании по законодательству США // Legal Concept = Правовая парадигма. $-2018 .-$ Т. 17 , № 4. -C. 113-116. -DOI: https://doi.org/10.15688/lc.jvolsu.2018.4.16

\section{Введение}

В настоящее время в мировой экономике происходит активное появление и развитие юридических лиц, которые находятся между собой в достаточно жесткой конкуренции. Поэтому, любой организации, в независимости от ее размеров, очень важна репутация. Репутация влияет на взаимоотношения с партнерами, помогает поддерживать контакт с потребителями, побороть конкурентов и способствует развитию бизнеса. Главную роль играет имидж. Существуют положительная и отрицательная репутация. Благодаря хорошей репутации у компании появляется возможность повышать ценность производимых ее товаров, соответственно увеличивается сумма продаж. Стабильное функционирование организации привлекает квалифицированных работников, а также банки, которые иногда помогают выстоять в экономически сложных ситуациях. В связи с этим, выработка законодателем действенных механизмов защиты деловой репутации юридических лиц является чрезвычайно актуальной, так как распространение порочащих сведений имеет долгосрочные последствия связанные, прежде всего, с финансовыми потерями, в том числе и в глобальном масштабе на всех рынках, на которых работает компания. В свою очередь это отражается на рынке труда, последнее вызывает негативные социальные последствия в обществе.

\section{Правовая природа диффамации по законодательству США}

Законодательство США основывается на традициях англосаксонской правовой се- мьи, в связи с чем, правовое регулирование отношений защиты деловой репутации подверглось активному влиянию английского права. В США, наряду с федеральным законодательством, существует и законодательство штатов, обладающих своим суверенитетом, который распространяется по территории всего штата, за исключением тех полномочий, что были отданы федеральному правительству. Следовательно, штаты на местном уровне могут расширить ряд полномочий, по сравнению с федеральными законами, в частности, конституции ряда штатов представлены в болеерасширенном виде, в отличии от Конституции США, но с соблюдением основных базовых начал федерального законодательства США. Также необходимо отметить, что значительную роль и в федеральном законодательстве и законодательстве отдельных штатов играет общее право, в частности показательно в этом плане законодательство Луизиана, где присутствуют некоторые черты романо-германского права.

В праве США выделяют такое понятие как диффамация (от лат. diffamo - «лишаю доброго имени»). В общем виде, это выявление неверных сведений, порочащих честь и достоинство лица или компании. Как утверждает американский юрист Роберт Вандерет: «Диффамация - это утверждение, являющееся ложным и не защищенным привилегиями, порочащее репутацию человека, побуждая других людей осуждать или ненавидеть его, или нанося ущерб бизнесу этого человека» [4]. Ложные сведения, которые нанесли ущерб лицу, именуют дискредитирующими.

В США каждый штат имеет свои законы о диффамации. Например, существует такой закон, как «Закон об обеспечении защи- 
ты конституционного наследия («SPEECH Act»), принятый в 2010 году, - о внесении поправок в Свод законов США, запрещающий признание и приведение в исполнение иностранных судебных решений о диффамации и некоторых иностранных судебных решений в отношении поставщиков интерактивных компьютерных услуг [2]. В законе упоминается определение диффамации, которая означает любое действие, а именно клевета или утверждение, которое является ложным, подрыв репутации, а также представления лица в плохом свете, приводящем к критике, бесчестью или осуждению.

В США диффамацию считают деликтом (гражданским правонарушением), однако иногда лицо, распространившее ложные сведения, которые причинили вред, может стать даже субъектом уголовно-правового преследования. Но, справедливости ради надо отметить, что случаи применения уголовной ответственности очень редки.

Как упоминалось ранее, в случае возникновения диффамации в средствах массовой информации четко прослеживается столкновение двух основных прав: на свободу слова и на защиту чести, достоинства и репутации. В связи с этим, соблюдение баланса между реализацией двух этих прав вызывает трудности не только в законодательстве, но и в доктрине, как в рамках национальной правовой системы, так и на мировой арене. В США главную роль играет право на свободу слова, в том числе в СМИ.

Как указывалось выше, законодательство США, касающееся данной проблематики, основывается на общем праве. Между тем, настоящее определение Первой поправки к Конституции США кардинально поменяло мнение американских судов к законам о диффамации. В качестве примера можно привести дело «Нью-Йорк Таймс против Салливана» [3], в нем Верховный суд США вынес решение о том, что одни оскорбительные суждения регулируются и защищаются Первой поправкой к Конституции США. Дело касалось газетной статьи, которая содержала нелестные высказывания об общественном деятеле. При этом суд указал на наличие в США «глубокой национальной приверженности тому принципу, что дебаты по воп- росам общественной значимости должны быть раскованными, надежно и широко открытыми». Суд признал, что в общественных обсуждениях деятельности политиков могут быть ошибки. Если эти ошибки сделаны обоснованно и обдуманно, то они должны быть защищены от ответственности за диффамацию. Судом было установлено правило, согласно которому государственные чиновники могут подать в суд на заявления, сделанные об их общественном поведении, только если заявления были сделаны со «злым умыслом» [1]. «Злой умысел» предполагает, что лицо, которое сделало заявление, знало, что содержащееся в нем утверждение не соответствует действительности, или относилось к своему заявлению безразлично, безрассудно, не заботясь о том, являются правдой его утверждения или нет (например, когда кто-то сомневается в истинности утверждения, но не потрудился проверить его перед дальнейшей публикацией).

Сведения являются порочащими по законодательству США, если только есть вина лица в их распространении. При этом, как следует из вышеприведенного судебного прецедента, ответчик должен действовать именно со «злым умыслом», если он распространяет порочащие сведения в отношении чиновников и т. д.

Можно выделить следующие общие условия привлечения лица к ответственности за распространение порочащих сведений: установлен факт распространения сведений, бремя доказывания которого возложено на истца; данное сведение было доступно третьему лицу (напечатано в книге, обнародовано на телевидении, сказано громко, так, чтобы его услышали... и т. д.); лицо должно сделать утвердительноезаявление, ане высказать свое мнение, так как в отношении последнего невозможно определить его подложность (если лицо распространяет достоверные сведения, порочащие лицо, но не в целях защиты общественных интересов - это не будет являться диффамацией); данные сведения должны наносить вред репутации, то есть поведение третьих лиц в отношении лица изменилось после получения в отношении последнего сведений, и не в лучшую сторону (отдельные лица прекратили общение, потеря работы и т. д.). 
Кроме того, «клеветническое» заявление не должно быть непривилегированным. Данное условие основывается на том, что важнее всего является свобода слова. Поэтому привилегированными являются заявления «лжесвидетелей», заявления конгрессменов, сделанные в Конгрессе США или в официальных материалах, даже если они говорят или пишут вещи, которые могли бы быть клеветническими.

Выводы. В России на законодательном уровне описанные вопросы подробно не урегулированы. Основным законом о диффамации является Гражданский кодекс России (ст. 152 ГК РФ), содержащий нормативное регулирование только общих вопросов защиты прав лица, в отношении которого распространены порочащие сведения. В этой связи представляются вполне обоснованными с доктринальной и правоприменительной точки зрения следующие положения законодательства США: порочащие сведения должны быть именно утверждением, а не мнением; оценка наличия порочащих сведений должна базироваться на анализе содержания в целом заявления (сообщения, и т. д.), а не на содержании отдельной части (куска), на анализе общего его смысла, который понятен среднестатистическому человеку.

\section{СПИСОК ЛИТЕРАТУРЫ}

1. Аболонин, Г. О. О правовых системах США и России / Г. О. Аболонин // Вестник гражданского процесса. - 2013. - № 6. - С. 157-179.

2. [Закон США об обеспечении защиты конституционного наследия SPEECH Act // Официальный интернет-портал U.S. Government Publishing
Office - Национального издательства США] . - Электрон. дан. - Режим доступа: http://www.gpo.gov/ fdsys/pkg/PLAW-111 publ223/html/PLAW111 publ223.htm.

3. [Решение Верховного суда США по делу New York Times Co. v. Sullivan 376 U.S. 254 (1964)// Архив решений Верховного суда США]. - Электрон. дан. - Режим доступа: https://supreme.justia.com/ cases/federal/us/376/254/case.html.

4. Самородов, Д. А. Понятие неприкосновенности чести и достоинства в законодательствах Великобритании, Франции, США, Германии и России / Д. А. Самородов // Вестник Московского университета им. С. Ю. Витте. Серия 2, Юридические науки. - 2016. - № 2 (9). - С. 43.

\section{REFERENCES}

1. Abolonin G.O. O pravovykh sistemakh SShA i Rossii [On the Legal Systems of the United States and Russia]. Vestnik grazhdanskogo protsessa, 2013, no. 6, pp. 157-179.

2. Zakon SShA ob obespechenii zashchity konstitutsionnogo naslediya Speech Act [US Law on Ensuring the Protection of the Constitutional Heritage Speech Act]. Official Internet portal U.S. Government Publishing Office. URL: http://www.gpo.gov/fdsys/ pkg/PLAW-111 publ223/html/PLAW-111publ223.htm.

3. Reshenie Verkhovnogo suda SShA po delu New York Times Co. v. Sullivan 376 U.S. 254 (1964) [The Decision of the US Supreme Court on the Case of the New York Times Co. v. Sullivan 376 U.S. 254 (1964)]. Archives of Decisions of the US Supreme Court. URL: https://supreme.justia.com/cases/federal/us/376/254/ case.html.

4. Samorodov D.A. Ponyatie neprikosnovennosti chesti i dostoinstva $\mathrm{v}$ zakonodatelstvakh Velikobritanii, frantsii, SShA, Germanii i Rossii [The Concept of Inviolability of Honor and Dignity in the Laws of the UK, France, USA, Germany and Russia]. Vestnik Moskovskogo universiteta im. S.Yu. Vitte. Seriya 2, Yuridicheskie nauki, 2016, no. 2 (9), p. 43.

\section{Information about the Author}

Vladimir V. Yastrebov, Postgraduate Student, Department of Civil Law and Process and International Private Law, Peoples' Friendship University of Russia, Miklukho-Maklaya St., 6, 117198 Moscow, Russian Federation, vladimir-soin2012@yandex.ru, https://orcid.org/0000-0003-1729-6752

\section{Информация об авторе}

Владимир Валерьевич Ястребов, аспирант кафедры гражданского права и процессе и международного частного права, Российский университет дружбы народов, ул. Миклухо-Маклая, 6, 117198 г. Москва, Российская Федерация, vladimir-soin2012@yandex.ru, https://orcid.org/00000003-1729-6752 